\title{
Multiple Disease Resistance in Interspecific Hybrids of Potato
}

\author{
S. H. Jansky, Professor, Department of Biology, University of Wisconsin-Stevens Point 54481; and D. I. Rouse, \\ Professor, Department of Plant Pathology, University of Wisconsin-Madison 53706
}

\begin{abstract}
Jansky, S. H., and Rouse, D. I. 2003. Multiple disease resistance in interspecific hybrids of potato. Plant Dis. 87:266-272.

Wild species of Solanum are excellent sources of disease resistance genes that may be incorporated into $S$. tuberosum through breeding. This study was initiated to determine whether multiple forms of disease resistance could be identified in interspecific Solanum hybrids. Thirty-two clones were evaluated for resistance to soft rot, common scab, black scurf, Verticillium wilt, and early blight. Most of the clones originated from populations that were not initially selected for disease resistance traits. Comparisons with the cultivars Atlantic, Russet Norkotah, and Russet Burbank indicated that all clones were more resistant than at least one cultivar for at least one disease resistance trait. Clone C545, which exhibited improved resistance to soft rot, scab, pitted scab, early dying disease, and early blight, appears to be an especially valuable source of disease resistance. The use of interspecific hybridization at the diploid level, combined with sexual polyploidization to return to the tetraploid level, provides a method to introduce multiple forms of disease resistance into advanced clones.
\end{abstract}

Additional keywords: Alternaria solani, Erwinia carotovora subsp. atroseptica, Pratylenchus penetrans, Rhizoctonia solani, soft rot, Streptomyces scabies, Verticillium dahliae

The potato (Solanum tuberosum L.) is an intensively managed crop that requires frequent applications of costly pesticides for high yield and quality; however, the environmental impacts of pesticides are well documented and government agencies continue to evaluate pesticide labels with the goal of reducing their use (41). In spite of the extensive use of pesticides, an estimated $22 \%$ of potato yield is lost per year to diseases and pests (37). Based on a total 2000 world production of 311 million metric tons (11), this amounts to 68 million tons of potatoes destroyed annually by pathogens and pests.

Host plant resistance offers the most cost-effective long-term approach to minimizing the effects of disease in potato. Although genes for resistance to almost all major potato diseases exist in wild Solanum spp. $(4,17,29)$, they have not been used widely in the development of current cultivars (44). Many breeding programs now are using wild species as sources of resistance genes and have developed

Corresponding author: S. H. Jansky

E-mail: sjansky@uwsp.edu

This work was funded in part by the Wisconsin Potato and Vegetable Growers Association, the UW System Applied Research Program, the USDA/ARS (59-1275-8-058), and the UWSP University Personnel Development Committee.

Accepted for publication 7 October 2002.

Publication no. D-2002-1230-02R

(C) 2003 The American Phytopathological Society segregating populations via crosses to haploids of $S$. tuberosum $(16,31,42,43)$. Populations with resistance to multiple diseases have been developed using wild germ plasm $(10,30)$. Some breeding programs emphasize the development of clones with multiple resistance traits $(24,35,36,40)$.

In 1994, 557 diploid interspecific clones were evaluated for resistance to Verticillium wilt, early blight, and common scab in a field used to screen for resistance to Verticillium dahliae. These clones were developed for a chip color inheritance study (45) and had not been selected for resistance to $V$. dahliae. High levels of resistance were identified in several clones and, after 5 years of intensive screening, two clones with near immunity to the fungus were selected from this population (18). The identification of high levels of resistance to $V$. dahliae in a relatively small, but highly diverse, population has led us to evaluate these interspecific hybrids for other valuable disease resistance traits.

In this study, diploid and tetraploid interspecific hybrids were screened for resistance to tuber soft rot caused by the bacterium Erwinia carotovora subsp. atroseptica (van Hall) Dye, common scab caused by the soilborne actinomycete Streptomyces scabies (Thaxter), black scurf caused by the soilborne fungus Rhizoctonia solani Kühn, potato early dying disease caused by the soilborne fungus $V$. dahliae Kleb. and the root lesion nematode Pratylenchus penetrans (Cobb) Filipjev \& Schuur. Stekh., and early blight caused by the fungus Alternaria solani Sorauer.

\section{MATERIALS AND METHODS}

Plant material. Clones from four populations were included in the multiple disease resistance analysis. The pedigrees of these clones are outlined in Table 1 . The $\mathrm{C}$ series clones were haploid S. tuberosum Gp. Tuberosum $(2 \mathrm{x}$ tbr $) \times$ wild species intercrosses developed for a cold chipping inheritance study (45). The I series consisted of progeny of haploid $\times$ wild species intercrosses involving $S$. berthaultii (ber), $S$. tarijense (tar), and S. chacoense (chc) crossed to tbr haploids. These clones were developed as potential sources of resistance to Colorado potato beetle (Leptinotarsa decemlineata Say) and green peach aphid (Myzus persicae Sulz.) (25). The T series clones were tetraploids from $4 \mathrm{x} \times 2 \mathrm{x}$ crosses in which the diploid parents were crosses between $2 \mathrm{x}$ tbr and either ber or tar. The $\mathrm{V}$ series clones were $2 \mathrm{x}$ tbr $\times$ chc or $2 \mathrm{x}$ tbr $\times S$. tuberosum Gp. Phureja (phu) germ plasm selected for resistance to $V$. dahliae in a 1992 field trial.

Field trials. All field trials were performed at the Hancock (Wisconsin) Agricultural Experiment Station on Plainfield loamy sand soil (92\% sand, 5\% silt, 3\% clay, and $<1 \%$ organic matter). Unless indicated otherwise, plants were grown according to Wisconsin Cooperative Extension Service guidelines. Fields were irrigated three times per week. Plots consisted of four plants, with $30 \mathrm{~cm}$ between plants.

In 1996, tubers from 29 test clones and the cultivars Atlantic, Russet Norkotah, and Russet Burbank were planted on 7 May in a field used to screen for resistance to $V$. dahliae. This field has been planted continuously to potato for more than 30 years and contains approximately $50 \mathrm{CFU}$ of $V$. dahliae per gram of soil. Streptomyces scabies and Rhizoctonia solani also are present in this field. Three to nine replications (determined by seed piece availability) were planted in an unbalanced randomized complete block design. Plants were rated weekly from 19 July through 23 August for vine maturity and early blight symptoms. Vine maturity was rated on a scale of 1 to 5 , where $1=$ dead, $2=$ prostrate, $3=$ post-flower, upright, $4=$ mid- to late-flower, and $5=$ early flower. Early blight was rated on a scale of 0 to 4 based on the percentage of foliage in increments of five percentage points covered with early blight lesions $(0=0,1=5$ to $25,2=$ 
30 to $50,3=55$ to 75 , and $4=80$ to $100 \%)$.

When the plants in a plot appeared to be within 1 week of senescence, the basal portions of stems from ground level to approximately $10 \mathrm{~cm}$ above the ground were collected in order to measure colonization by $V$. dahliae. Sap was squeezed from the basal portion of each stem and $100 \mu 1$ was plated on NPX medium (6). Sap was spread evenly on the plate with a sterile bent glass rod. After a 2-week incubation period in the dark at room temperature, the number of $V$. dahliae colonies per plate was counted. Stem colonization also was measured using dried stems. Basal stem segments were dried, ground with a Wiley mill, and passed through a 40-mesh screen. A 10-mg sample of each stem was plated on NPX medium by gently tapping the weighing paper over the petri dish. Colonies of $V$. dahliae were counted after a 2-week incubation period in the dark at room temperature.

Plots were harvested by hand on 9 October and tubers were stored at room temperature until they were scored for scab, black scurf, and soft rot. Five tubers from each plot were collected and washed in preparation for scab and black scurf rating. Scab severity was determined on 11 October by estimating the total surface area of each tuber covered with scab and pitted scab, and incidence of black scurf was

Table 1. Pedigrees of clones used in resistance evaluations

\begin{tabular}{|c|c|}
\hline Clone & Female $\times$ male parent ${ }^{\mathbf{a}}$ \\
\hline $\mathrm{C} 118$ & $(\mathrm{~W} 730 \times \operatorname{tar}) \times(\mathrm{H} 322 \times$ ber-tar $)$ \\
\hline C206 & $($ H551 $\times$ ber-tar $) \times($ W973 $\times$ ber-tar $)$ \\
\hline $\mathrm{C} 251$ & $(\mathrm{H} 551 \times$ ber-tar $) \times(\mathrm{H} 482 \times$ ber-tar $)$ \\
\hline C264 & $(\mathrm{H} 551 \times$ ber-tar $) \times(\mathrm{H} 322 \times$ ber-tar $)$ \\
\hline C287 & $(\mathrm{W} 730 \times$ ber-tar $) \times(\mathrm{W} 730 \times$ tar $)$ \\
\hline C292 & $($ W730 $\times$ ber-tar $) \times(H 322 \times$ ber-tar $)$ \\
\hline $\mathrm{C} 41$ & $(\mathrm{H} 551 \times \mathrm{spl}) \times(\mathrm{H} 482 \times$ ber-tar $)$ \\
\hline C414 & $(\mathrm{W} 973 \times \mathrm{spl}) \times(\mathrm{H} 322 \times$ ber-tar $)$ \\
\hline C442 & $(\mathrm{W} 973 \times \mathrm{spl}) \times(\mathrm{W} 1887 \times \mathrm{grl})$ \\
\hline C447 & $(\mathrm{W} 973 \times \mathrm{spl}) \times(\mathrm{W} 1887 \times \mathrm{grl})$ \\
\hline $\mathrm{C} 470$ & $(\mathrm{~W} 1887 \times \mathrm{grl}) \times(\mathrm{H} 551 \times \mathrm{spl})$ \\
\hline C499 & $(\mathrm{W} 1887 \times$ grl $) \times(\mathrm{H} 322 \times$ ber-tar $)$ \\
\hline C51 & $(\mathrm{H} 551 \times \mathrm{spl}) \times(\mathrm{H} 482 \times$ ber-tar $)$ \\
\hline C52 & $(\mathrm{H} 551 \times \mathrm{spl}) \times(\mathrm{H} 482 \times$ ber-tar $)$ \\
\hline C545 & $(\mathrm{H} 551 \times \mathrm{chc}) \times(\mathrm{W} 730 \times$ ber-tar $)$ \\
\hline C558 & $($ W730 $\times$ buk $) \times($ H322 $\times$ ber-tar $)$ \\
\hline C571 & $($ W $973 \times$ buk $) \times(\mathrm{H} 551 \times$ ber-tar $)$ \\
\hline C589 & $($ W973 $\times$ buk $) \times($ H373 $\times$ ber-tar $)$ \\
\hline C590 & $($ W973 $\times$ buk $) \times($ H373 $\times$ ber-tar $)$ \\
\hline C6 & $(\mathrm{W} 730 \times \mathrm{spl}) \times(\mathrm{H} 551 \times \mathrm{spl})$ \\
\hline C600 & $($ W973 $\times$ buk $) \times($ H373 $\times$ ber-tar $)$ \\
\hline C635 & $(\mathrm{A} 121 \mathrm{a} \times \mathrm{chc}) \times(\mathrm{W} 730 \times$ ber-tar $)$ \\
\hline $\mathrm{I} 35.05$ & {$[($ tbr $\times$ chc $) \times$ ber $] \times$ ber } \\
\hline T56.08 & $\mathrm{W} 231 \times(\mathrm{W} 2838 \times \operatorname{tar})$ \\
\hline T56.17 & $\mathrm{W} 231 \times(\mathrm{W} 2838 \times \operatorname{tar})$ \\
\hline $\mathrm{T} 58.10$ & $\mathrm{~W} 231 \times(\mathrm{W} 2236 \times \operatorname{tar})$ \\
\hline V48.03 & Att $401 \times$ chc \\
\hline V50.02 & At1 $401 \times$ phu \\
\hline V51.03P & W457 $\times$ chc \\
\hline V51.03R & W457 $\times$ chc \\
\hline V54.04 & W7 $25 \times$ phu \\
\hline V54.19 & W725 $\times$ phu \\
\hline
\end{tabular}

${ }^{\mathrm{a}} \operatorname{tar}=$ Solanum tarijense, ber $=S$. berthaultii, $\mathrm{spl}=S$. sparsipilum, grl $=S$. gourlayi, chc $=S$. chacoense, buk $=S$. bukasovii, $\mathrm{phu}=S$. phureja, $\mathrm{W} 231=4 \mathrm{x}$ Gp. Tuberosum, all others $=2 \mathrm{x}$ Gp. Tuberosum. determined by counting the number of tubers with lesions. Tubers were considered to have pitted scab if any lesions penetrated into the tuber.

Between 17 November and 8 December, 19 test clones and 'Russet Norkotah' from the 1996 field trial were evaluated for soft rot resistance. Tubers free of external defects, including scab and black scurf, were washed in soapy water, followed by a fresh water rinse. Then, they were immersed in $0.5 \%$ sodium hypochlorite twice for 20 min each time, rinsed in sterile distilled water, sprayed with $95 \%$ ethanol, and allowed to air dry. Each tuber was injected at two locations to a depth of $10 \mathrm{~mm}$ with 10 $\mu 1$ of a $10^{8} \mathrm{CFU} / \mathrm{ml}$ suspension of E. carotovora subsp. atroseptica (ECA-SR 8). The suspension was prepared from cultures of the bacterium grown overnight in trypticase soy broth, and diluted to the desired concentration with sterile distilled water. Each tuber also was inoculated with $10 \mu \mathrm{l}$ of sterile water as a control. One tuber per clone was evaluated on each of two dates and two tubers per clone were evaluated on the third date (26 February, 12 March, and 9 April). Inoculated tubers were placed in sterile sealed containers on moist paper towels and incubated for 5 days at room temperature and high humidity. Following the incubation period, tubers were sliced vertically through the inoculation points and the diameter of the decayed tissue was measured. The diameter of damaged tissue at the control injection site also was measured and subtracted from the diameter of decayed tissue at inoculated sites to obtain a "diameter of infection" rating.

In 1997, 25 clones and the cultivars Russet Norkotah and Russet Burbank were planted on 8 May in a field with low levels of $V$. dahliae ( $<5 \mathrm{CFU} / \mathrm{g}$ of soil) and $P$. penetrans. The trial consisted of two replicates of four-plant plots in a randomized complete block design. Each plot was inoculated with approximately 20,000 culture-grown $P$. penetrans individuals (mixture of eggs, juveniles, and adults). Nematodes were cultured on sweet corn roots grown on Gamborg's medium without auxins or cytokinins. Nematodes were washed from the culture, the concentration was adjusted with distilled water, and $5 \mathrm{ml}$ of the suspension was injected with a syringe at a depth of $9 \mathrm{~cm}$ around emerging plants. Each plot was also inoculated by placing $10^{7} \mathrm{CFU}$ of $V$. dahliae in the furrow at planting. The inoculum of $V$. dahliae was made by inoculating sterilized rye seed with a 3-day-old culture of $V$. dahliae grown on Czapek's Dox liquid broth and incubating it for 6 weeks. The seeds then were dried at room temperature and ground in a Wiley mill. The inoculum was plated and the concentration determined to be $10^{5}$ propagules/g of ground rye seed.

Stems were rated for vine maturity, early blight symptoms, and stem colonization by $V$. dahliae as described in 1996, beginning on 30 July and ending on 8 September. As in 1996, approximately 1 week before senescence, stems were collected from each clone to quantify $V$. dahliae in the sap. Populations of $P$. penetrans in the roots also were determined. Approximately $2 \mathrm{~g}$ of root tissue per plot was collected in midAugust and placed in a Baermann funnel, and nematodes were recovered after a $48-\mathrm{h}$ incubation period. The number of $P$. penetrans nematodes were converted to number per gram of root tissue.

In 1998, an experiment designed to evaluate multiple disease resistance was planted on 29 April. Three trials (A, B, and C) were planted in a field with low levels of $V$. dahliae ( $<5 \mathrm{CFU} / \mathrm{g}$ of soil). All trials received standard cultural practices, including pesticide and fungicide applications, unless otherwise noted. Trial A, in which disease incidence was expected to be low, was the control trial. Trial B was identical to $\mathrm{A}$, except that it did not receive fungicide treatments during the growing season. On 19 May, each plot in trial C was inoculated with approximately $10^{7}$ CFU of $V$. dahliae and 80,000 culturegrown $P$. penetrans individuals (mixture of eggs, juveniles, and adults) as described in 1997. A fourth trial (trial D) was planted on the field used to screen for Verticillium wilt resistance described in 1996 and also inoculated with $10^{7} \mathrm{CFU}$ of $V$. dahliae per 
plot as described in 1997. In each trial, 31 clones and the cultivars Atlantic and Russet Norkotah were planted in four-plant plots in a randomized complete block design with four replications. Plants in trial A were rated for maturity on 7 August, using the scale described previously. Plants in trial B were rated for early blight lesions based on visual estimate of percentage of foliage free of early blight lesions $(100=$ no lesions; $0=$ no foliage free of lesions). In trials $\mathrm{C}$ and $\mathrm{D}$, stems were collected when plants were within 1 week of senescence and assayed for colonization by $V$. dahliae as described above. In trial $\mathrm{C}$, roots were assayed for $P$. penetrans as described previously.

At harvest, five random tubers from each plot in trial D were rated for scab and black scurf as described in 1996.

Statistical analyses. The General Linear Model procedure of SAS (1994; SAS Institute, Cary, NC) was used for analyses of variance (ANOVA). A separate one-way ANOVA was performed for each trait measured, where clones and cultivars were treatments. A two-way ANOVA with year and clone or cultivars as the factors was used to look at the effect of year on the performance of the clones or cultivars. A separate one-way ANOVA ( $t$ test) was done for each clone-cultivar comparison. The PROC CORR procedure in SAS was used to calculate Pearson correlation coefficients. Colony counts of $V$. dahliae were transformed using $\log _{10}(\mathrm{CFU}+1)$. For the soft rot analysis, each tuber was considered to be a replicate.

\section{RESULTS}

Resistance to soft rot. The average diameter of tissue decayed by soft rot in the cultivar standard Russet Norkotah was 8.4 $\mathrm{mm}$. Of the 19 clones, 3 (16\%) had significantly smaller, less-decayed tissue than Russet Norkotah (Table 2). The mean di- ameter of infection of the resistant clones C118, C545, and V54.19 was 4.4, 4.6, and $0.6 \mathrm{~mm}$, respectively.

Resistance to scab. The average tuber surface area covered by scab was significantly higher $(P<0.0001)$ in $1996(18 \%)$ than in $1998(12 \%)$. The clone-year interaction was also highly significant $(P \leq$ 0.0001). In 1998, none of the test clones had less scab than Atlantic or Russet Norkotah. In 1996, 6 (C292, C41, C447, C635, T56.17, and V50.02) of the 29 clones $(21 \%)$ were more resistant to scab than all three cultivars (Table 2). Seven additional clones (C118, C287, C442, C545, C558, C590, and C6) were more resistant than at least one cultivar.

The mean number of tubers exhibiting pitted scab lesions across all clones in 1996 $(11 \%)$ was not significantly different than in $1998(16 \%)$. The clone-year interaction was not significant. The incidence of pitted scab in Russet Norkotah and Russet

Table 2. Comparisons between cultivars and test clones for resistance to soft rot, common scab, and black scurf ${ }^{\mathrm{a}}$

\begin{tabular}{|c|c|c|c|c|c|c|c|c|c|c|c|c|c|c|}
\hline \multirow[b]{3}{*}{ Clone } & \multicolumn{2}{|c|}{ Soft $\operatorname{rot}^{b}$} & \multicolumn{4}{|c|}{ Scab $^{c}$} & \multicolumn{2}{|c|}{ Pitted scab $(1996)^{d}$} & \multicolumn{3}{|c|}{ Pitted scab (1998)e } & \multicolumn{3}{|c|}{ Black scurf $^{f}$} \\
\hline & \multirow[b]{2}{*}{ Mean } & \multirow{2}{*}{$\frac{\text { Comp }}{\text { RN }}$} & \multirow[b]{2}{*}{ Mean } & \multicolumn{3}{|c|}{ Comp } & \multirow[b]{2}{*}{ Mean } & \multirow{2}{*}{$\frac{\text { Comp }}{\text { Atl }}$} & \multirow[b]{2}{*}{ Mean } & \multicolumn{2}{|c|}{ Comp } & \multirow[b]{2}{*}{ Mean } & \multicolumn{2}{|c|}{ Comp } \\
\hline & & & & Atl & $\mathbf{R N}$ & RB & & & & Atl & $\mathbf{R N}$ & & Atl & $\mathbf{R N}$ \\
\hline C118 & 4.4 & $* *$ & 7.9 & $* *$ & $*$ & - & 6.7 & $* *$ & 20.0 & - & - & 20.0 & $* *$ & - \\
\hline C206 & 18.9 & - & 21.2 & - & - & - & 8.0 & $*$ & 0.0 & - & - & 0.0 & $* *$ & $*$ \\
\hline $\mathrm{C} 251$ & 12.2 & - & 33.0 & - & - & - & 46.7 & - & 10.0 & - & - & 40.0 & $*$ & - \\
\hline C264 & nt & nt & 65.8 & - & - & - & 31.7 & - & 25.0 & - & - & 10.0 & $* *$ & $*$ \\
\hline C287 & $\mathrm{nt}$ & $\mathrm{nt}$ & 6.2 & $* *$ & $* *$ & - & 0.0 & $* *$ & 0.0 & - & $*$ & 33.3 & $*$ & - \\
\hline C292 & 10.2 & - & 2.5 & $*$ & $*$ & $*$ & 0.0 & $*$ & 20.0 & - & - & 60.0 & - & - \\
\hline $\mathrm{C} 41$ & 13.3 & - & 0.7 & $*$ & $*$ & $*$ & 0.0 & $*$ & 20.0 & - & - & 0.0 & $* *$ & $*$ \\
\hline $\mathrm{C} 414$ & nt & nt & 29.4 & - & - & - & 0.0 & $* *$ & 5.0 & - & - & 0.0 & $* *$ & $* *$ \\
\hline $\mathrm{C} 442$ & 8.6 & - & 12.6 & $*$ & - & - & 0.0 & $* *$ & 0.0 & $*$ & $*$ & 5.0 & $* *$ & $* *$ \\
\hline C447 & $\mathrm{nt}$ & nt & 4.5 & $*$ & $*$ & $*$ & 0.0 & $*$ & 20.0 & - & - & 0.0 & $* *$ & $*$ \\
\hline $\mathrm{C} 470$ & 18.2 & - & 17.0 & - & - & - & 20.0 & - & 13.3 & - & - & 13.3 & $* *$ & $*$ \\
\hline C499 & nt & nt & $\mathrm{nt}$ & $\mathrm{nt}$ & $\mathrm{nt}$ & $\mathrm{nt}$ & nt & nt & 0.0 & $*$ & $*$ & 20.0 & $* *$ & - \\
\hline C51 & 6.9 & - & 35.3 & - & - & - & 22.2 & - & 20.0 & - & - & 65.0 & - & - \\
\hline C52 & $\mathrm{nt}$ & nt & 33.3 & - & - & - & 6.7 & $* *$ & 0.0 & - & - & 0.0 & $* *$ & $*$ \\
\hline C545 & 4.6 & $*$ & 12.7 & $*$ & - & - & 2.2 & $* *$ & 0.0 & $*$ & $*$ & 57.5 & - & - \\
\hline C558 & $\mathrm{nt}$ & nt & 12.4 & $*$ & - & - & 0.0 & $* *$ & 5.0 & - & - & 10.0 & $* *$ & $*$ \\
\hline C571 & 8.8 & - & 16.0 & - & - & - & 5.0 & $* *$ & 40.0 & - & - & 30.0 & $* *$ & - \\
\hline C589 & 12.8 & - & 20.4 & - & - & - & 48.0 & - & 45.0 & - & - & 10.0 & $* *$ & $*$ \\
\hline C590 & 16.6 & - & 11.3 & $*$ & - & - & 5.0 & $* *$ & 15.0 & - & - & 10.0 & $* *$ & - \\
\hline C6 & nt & nt & 10.4 & $*$ & - & - & 0.0 & $* *$ & 0.0 & - & - & 33.3 & - & - \\
\hline C600 & 8.8 & - & 13.3 & - & - & - & 3.3 & $* *$ & 26.7 & - & - & 6.7 & $* *$ & - \\
\hline C635 & $\mathrm{nt}$ & $\mathrm{nt}$ & 8.4 & $* *$ & $*$ & $*$ & 42.2 & - & 20.0 & - & - & 15.0 & $* *$ & - \\
\hline I35.05 & 10.3 & - & 17.3 & - & - & - & 2.5 & $* *$ & 12.5 & - & - & 10.0 & $* *$ & $*$ \\
\hline Т56.08 & $\mathrm{nt}$ & $\mathrm{nt}$ & 21.4 & - & - & - & 0.0 & $* *$ & 10.0 & - & - & 40.0 & $* *$ & - \\
\hline Т56.17 & 6.0 & - & 8.0 & $* *$ & $*$ & $*$ & 5.0 & $* *$ & 0.0 & $*$ & $*$ & 45.0 & $*$ & - \\
\hline T58.10 & 11.9 & $\mathrm{nt}$ & 16.7 & - & - & - & 0.0 & $* *$ & 0.0 & - & - & 0.0 & $* *$ & $*$ \\
\hline V48.03 & 11.1 & - & 17.3 & - & - & - & 20.3 & - & $\mathrm{nt}$ & $\mathrm{nt}$ & $\mathrm{nt}$ & $\mathrm{nt}$ & nt & $\mathrm{nt}$ \\
\hline V50.02 & 7.5 & - & 0.0 & $*$ & $*$ & $*$ & 0.0 & $*$ & nt & $\mathrm{nt}$ & nt & $\mathrm{nt}$ & nt & nt \\
\hline V51.03P & nt & nt & $\mathrm{nt}$ & nt & nt & nt & $\mathrm{nt}$ & nt & 10.0 & - & - & 0.0 & $* *$ & $* *$ \\
\hline V51.03R & nt & $\mathrm{nt}$ & $\mathrm{nt}$ & nt & nt & $\mathrm{nt}$ & $\mathrm{nt}$ & $\mathrm{nt}$ & 40.0 & - & - & 40.0 & $*$ & - \\
\hline V54.04 & $\mathrm{nt}$ & nt & - & - & - & - & - & - & 0.0 & $*$ & - & 40.0 & $*$ & - \\
\hline V54.19 & 0.6 & $* *$ & 12.5 & - & - & - & 0.0 & $* *$ & 0.0 & $*$ & $*$ & 0.0 & $* *$ & $* *$ \\
\hline
\end{tabular}

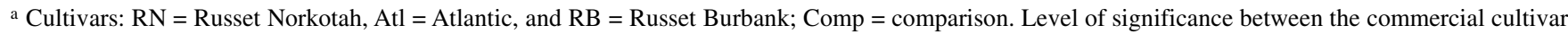
and the clone for the disease rating as determined by $t$ test, where $* *=$ clone is more resistant than the cultivar at $P \leq 0.01, *=$ clone is more resistant than the cultivar at $P \leq 0.05,-=$ difference is not significant or the clone is significantly more susceptible than the cultivar, and nt $=$ not tested.

${ }^{\mathrm{b}}$ Mean diameter of decayed tissue around two sites on each tuber injected with Erwinia carotovora subsp. atroseptica following harvest in 1996. Mean value for Russet Norkotah was $8.4 \mathrm{~mm}$.

${ }^{\mathrm{c}}$ Mean percent tuber surface area covered with scab lesions in 1996. Mean values for Atlantic, Russet Norkotah, and Russet Burbank were 27, 19, and $18 \%$, respectively. Clones were not different from commercial cultivars in 1998 (data not shown).

${ }^{\mathrm{d}}$ Mean percentage of tubers with pitted scab in 1996. Mean values for Atlantic, Russet Norkotah, and Russet Burbank were 44, 7, and 0\%, respectively. No test clone outperformed Russet Norkotah or Russet Burbank.

${ }^{e}$ Mean percentage of tubers with pitted scab in 1998. Mean values for Atlantic and Russet Norkotah were 25 and 30\%, respectively.

${ }^{\mathrm{f}}$ Mean percentage of tubers with black scurf lesions in 1998. Mean values for Atlantic and Russet Norkotah were 90 and 70\%, respectively. Clones were not different from commercial cultivars in 1996 (data not shown). 
Burbank was less than 10\% in 1996 and none of the clones had significantly less pitted scab. Clones with significantly lower levels of pitted scab than Atlantic in 1996 and 1998 and Russet Norkotah in 1998 were C442, C545, T56.17, and V54.19 (Table 2).

Although not numerically high $(r=$ 0.27 ), the correlation coefficient between the percent surface area covered by scab and the percentage of tubers with pitted scab was highly significant $(P \leq 0.0001)$.

Resistance to black scurf. Year $(P \leq$ $0.0001)$ and clone-year $(P \leq 0.0011)$ effects were highly significant for the percentage of tubers with lesions caused by $R$. solani. Incidence was higher across all clones in 1998 (27\%) than in $1996(7 \%)$. None of the clones in 1996 had significantly less scurf than the cultivars.
In 1998, the incidence of black scurf in 14 of 30 test clones $(47 \%)$ was significantly lower than Atlantic and Russet Norkotah (Table 2). Mean percentage of scurf was 90 and $70 \%$ for Atlantic and Russet Norkotah, respectively.

The incidence of black scurf was significantly correlated with the incidence of pitted scab ( $r=0.15, P \leq 0.0047)$, but it was not correlated with percentage of tuber surface area covered with scab $(r=-0.05$, $P=0.32$ ).

Resistance to Verticillium wilt. Year and year-clone effects in the 1996 and 1998 trials on the screen for Verticillium wilt resistance were highly significant $(P \leq$ 0.0001 ). Average populations of $V$. dahliae in the sap were higher in 1996 (552 CFU) than in 1998 (392 CFU). In the 1997 and 1998 trials for $V$. dahliae $+P$. penetrans, populations of $V$. dahliae in the sap were higher in 1997 (598 CFU) than in 1998 (139 CFU). In both years, $P$. penetrans was present in root samples of all clones, indicating that inoculation was successful, but nematode counts in the roots were highly variable and differences among clones were not detected. The average number of nematodes recovered per gram of root in the clones ranged from 2 to 2,328 in 1997 and 2 to 1,083 in 1998.

In 1998, mean stem colonization determined by populations of $V$. dahliae in the sap and dried stem tissue was significantly higher $(P<0.0001)$ in the trial with $V$. dahliae alone than in the trial with $V$. dahliae $+P$. penetrans. In the cultivars grown on the screening field, populations of $V$. dahliae in stem sap were higher than populations in dried stem tissue. The

Table 3. Comparisons of populations of Verticillium dahliae in stem tissue between cultivars and clones ${ }^{\mathrm{a}}$

\begin{tabular}{|c|c|c|c|c|c|c|c|c|c|c|c|c|c|c|c|c|c|c|c|}
\hline \multirow[b]{3}{*}{ Clone } & \multirow[b]{3}{*}{ Mean } & \multicolumn{3}{|c|}{1996 sap $^{\mathrm{b}}$} & \multirow{2}{*}{\multicolumn{3}{|c|}{$\begin{array}{c}\begin{array}{c}1997+P . \text { penetrans } \\
\text { sap }^{\mathrm{c}}\end{array} \\
\text { Comparison } \\
\end{array}$}} & \multicolumn{3}{|c|}{1998 sap $^{d}$} & \multicolumn{3}{|c|}{1998 dry $^{e}$} & \multicolumn{3}{|c|}{$\begin{array}{c}1998+P . \text { penetrans }^{\text {sap }} \\
\end{array}$} & \multicolumn{3}{|c|}{$\underset{\text { dry }^{\mathrm{g}}}{1998}+\begin{array}{c}\text { P. penetrans } \\
\end{array}$} \\
\hline & & \multicolumn{3}{|c|}{ Comparison } & & & & \multirow[b]{2}{*}{ Mean } & \multicolumn{2}{|c|}{ Comparison } & \multirow[b]{2}{*}{ Mean } & \multicolumn{2}{|c|}{ Comparison } & \multirow[b]{2}{*}{ Mean } & \multicolumn{2}{|c|}{ Comparison } & \multirow[b]{2}{*}{ Mean } & \multicolumn{2}{|c|}{ Comparison } \\
\hline & & Atl & $\mathbf{R N}$ & RB & Mean & Atl & $\mathbf{R N}$ & & Atl & $\mathbf{R N}$ & & Atl & $\mathbf{R N}$ & & Atl & $\mathbf{R N}$ & & Atl & $\mathbf{R N}$ \\
\hline C118 & 2.5 & $* *$ & - & - & 1.0 & - & - & 1.4 & * & - & 0.6 & - & - & 0.2 & $* *$ & $* *$ & 0.1 & $* *$ & $* *$ \\
\hline C206 & 1.1 & $* *$ & $* *$ & $*$ & nt & - & - & 0.7 & $*$ & - & 0.2 & - & - & 0.2 & $* *$ & $*$ & 0.0 & $* *$ & $* *$ \\
\hline $\mathrm{C} 251$ & 2.4 & $* *$ & $*$ & - & $\mathrm{nt}$ & - & - & 0.3 & $* *$ & - & 0.3 & - & - & 0.6 & - & - & 0.5 & - & - \\
\hline C264 & 1.2 & $* *$ & $* *$ & $*$ & 1.3 & - & - & 1.9 & - & - & 0.7 & - & - & 1.5 & $*$ & - & 0.2 & $*$ & $* *$ \\
\hline C287 & 0.2 & $* *$ & $* *$ & $* *$ & 0.0 & $* *$ & $* *$ & 0.3 & $* *$ & $*$ & 0.1 & $* *$ & $*$ & 0.0 & $* *$ & $* *$ & 0.3 & - & $*$ \\
\hline C292 & - & $\mathrm{nt}$ & $\mathrm{nt}$ & $\mathrm{nt}$ & 2.0 & - & - & 2.3 & - & - & 0.7 & - & - & 1.0 & - & - & 0.4 & - & - \\
\hline C41 & - & $\mathrm{nt}$ & $\mathrm{nt}$ & $\mathrm{nt}$ & 2.6 & - & - & 0.6 & $* *$ & $* *$ & 0.2 & $* *$ & - & 0.0 & $* *$ & $* *$ & 0.3 & - & $*$ \\
\hline C414 & 3.0 & - & - & - & 1.9 & - & - & 1.6 & - & - & 0.6 & - & - & 0.4 & $*$ & - & 0.2 & $* *$ & $* *$ \\
\hline C442 & 2.9 & - & - & - & nt & $\mathrm{nt}$ & $\mathrm{nt}$ & 2.2 & - & - & 0.5 & - & - & 0.9 & - & - & 0.1 & $* *$ & $* *$ \\
\hline C447 & 2.4 & - & - & - & $\mathrm{nt}$ & $\mathrm{nt}$ & $\mathrm{nt}$ & 1.7 & $*$ & - & 0.6 & - & - & 0.7 & $*$ & - & 0.4 & - & - \\
\hline C470 & 1.6 & $*$ & $* *$ & $* *$ & 1.5 & - & - & 1.9 & - & - & 1.1 & - & - & 1.2 & - & - & 0.4 & - & - \\
\hline C499 & - & $\mathrm{nt}$ & $\mathrm{nt}$ & nt & 2.5 & - & - & 0.9 & $* *$ & - & 0.4 & $*$ & - & 0.1 & $* *$ & $* *$ & 0.2 & $*$ & $* *$ \\
\hline C51 & 2.1 & $* *$ & - & - & 2.4 & - & - & 1.3 & $* *$ & - & 0.3 & $*$ & - & 0.1 & $* *$ & $* *$ & 0.2 & $* *$ & $* *$ \\
\hline C52 & - & $\mathrm{nt}$ & $\mathrm{nt}$ & $\mathrm{nt}$ & 2.6 & - & - & 0.8 & $* *$ & - & 0.7 & - & - & 0.4 & $*$ & - & 0.3 & - & - \\
\hline C545 & 1.1 & $* *$ & $* *$ & $* *$ & 0.0 & $* *$ & $* *$ & 0.2 & $* *$ & $*$ & 0.1 & $* *$ & $*$ & 0.5 & $*$ & - & 0.0 & $* *$ & $* *$ \\
\hline C558 & 2.3 & $* *$ & - & - & 2.3 & - & - & 1.9 & - & - & 0.5 & - & - & 1.1 & - & - & 0.5 & - & - \\
\hline C571 & 0.7 & $*$ & $* *$ & $* *$ & 1.1 & - & - & 1.8 & - & - & 0.7 & - & - & nt & $\mathrm{nt}$ & $\mathrm{nt}$ & 0.0 & $* *$ & $* *$ \\
\hline C589 & 2.2 & $*$ & - & - & nt & $\mathrm{nt}$ & $\mathrm{nt}$ & 0.9 & $* *$ & - & 0.3 & $* *$ & - & 0.3 & $* *$ & $* *$ & 0.3 & - & $* *$ \\
\hline C590 & 2.2 & $* *$ & $*$ & - & 0.2 & - & - & 2.0 & - & - & 0.5 & - & - & 1.0 & - & - & 0.8 & - & - \\
\hline C6 & 2.0 & $* *$ & * & - & 0.9 & - & - & 1.8 & - & - & 0.2 & $*$ & - & nt & nt & $\mathrm{nt}$ & 0.1 & - & - \\
\hline C600 & 2.4 & $* *$ & $*$ & - & 2.3 & - & - & 1.2 & $*$ & - & 0.2 & $*$ & - & nt & $\mathrm{nt}$ & $\mathrm{nt}$ & 0.2 & - & - \\
\hline C635 & 3.1 & - & - & - & 1.3 & - & - & 2.4 & - & - & 1.1 & - & - & 1.1 & - & - & 0.7 & - & - \\
\hline I35.05 & 2.2 & - & $*$ & $*$ & 2.3 & - & - & 0.7 & ** & $*$ & 0.2 & $* *$ & - & 0.2 & $* *$ & $* *$ & 0.0 & $* *$ & $* *$ \\
\hline T56.08 & 2.7 & - & - & - & 2.6 & - & - & 1.0 & $* *$ & - & 0.1 & $* *$ & - & 0.6 & - & - & 0.2 & - & - \\
\hline T56.17 & 2.1 & $* *$ & $*$ & - & 0.4 & $*$ & $* *$ & 1.1 & $* *$ & - & 0.3 & $* *$ & - & 0.0 & $* *$ & $*$ & 0.2 & $* *$ & $* *$ \\
\hline T58.10 & - & $\mathrm{nt}$ & nt & nt & 1.2 & - & - & 1.9 & - & - & 0.5 & - & - & 1.8 & - & - & 0.4 & - & - \\
\hline V48.03 & 1.1 & $*$ & $*$ & $*$ & 1.5 & - & - & 2.3 & - & - & 0.7 & - & - & 2.5 & - & - & 0.5 & - & - \\
\hline V50.02 & - & $\mathrm{nt}$ & $\mathrm{nt}$ & $\mathrm{nt}$ & $\mathrm{nt}$ & $\mathrm{nt}$ & $\mathrm{nt}$ & 1.0 & $*$ & - & 0.4 & - & - & 0.4 & $*$ & - & 0.1 & - & - \\
\hline V51.03P & - & $\mathrm{nt}$ & $\mathrm{nt}$ & $\mathrm{nt}$ & 0.5 & - & - & 0.6 & $* *$ & $* *$ & 0.0 & $* *$ & $* *$ & 0.3 & $* *$ & $* *$ & 0.1 & $*$ & $* *$ \\
\hline V51.03R & $\mathrm{nt}$ & $\mathrm{nt}$ & nt & nt & 2.5 & - & - & 1.9 & - & - & 0.5 & - & - & 1.7 & - & - & 0.7 & - & - \\
\hline V54.04 & $\mathrm{nt}$ & $\mathrm{nt}$ & $\mathrm{nt}$ & $\mathrm{nt}$ & $\mathrm{nt}$ & $\mathrm{nt}$ & $\mathrm{nt}$ & 1.8 & - & - & 0.6 & - & - & 0.3 & - & - & 0.3 & - & $*$ \\
\hline V54.19 & 2.4 & $*$ & $*$ & $*$ & 0.6 & - & - & 0.5 & $* *$ & $* *$ & 0.3 & $*$ & - & 1.2 & - & - & 0.3 & - & $*$ \\
\hline
\end{tabular}

${ }^{\mathrm{a}}$ Cultivars: Atl $=$ Atlantic, $\mathrm{RN}=$ Russet Norkotah, and RB $=$ Russet Burbank. Level of significance between the commercial cultivar and the clone for the disease rating as determined by $t$ test, where $* *=$ clone is more resistant than the cultivar at $P \leq 0.01, *=$ clone is more resistant than the cultivar at $P \leq$ $0.05,-=$ difference is not significant or the clone is significantly more susceptible than the cultivar, and $\mathrm{nt}=$ not tested.

${ }^{\mathrm{b}}$ Clones grown in soil infested with $V$. dahliae $\left(50 \mathrm{CFU} / \mathrm{g}\right.$ of soil) in $1996 . \log _{10}(\mathrm{CFU}+1) \mathrm{V}$. dahliae in $100 \mu 1$ of stem sap. Mean values for Atlantic, Russet Norkotah, and Russet Burbank were 3.0, 2.9, and 2.9, respectively.

${ }^{c}$ Clones inoculated with $10^{7} \mathrm{CFU}$ of $V$. dahliae and 20,000 Pratylenchus penetrans individuals per plot in 1997. $\log _{10}(\mathrm{CFU}+1) \mathrm{V}$. dahliae in 100 $\mu 1$ of stem sap. Mean values for Atlantic and Russet Norkotah were 2.4 and 2.6, respectively.

${ }^{\mathrm{d}}$ Clones inoculated with $10^{7} \mathrm{CFU}$ of $V$. dahliae and grown in soil infested with $V$. dahliae (50 cfu/g soil) in 1998. $\log _{10}(\mathrm{CFU}+1) \mathrm{V}$. dahliae in $100 \mu 1$ of stem sap. Mean values for Atlantic and Russet Norkotah were 2.4 and 1.4, respectively.

${ }^{\mathrm{e}}$ Clones inoculated with $10^{7} \mathrm{CFU}$ of $V$. dahliae and grown in soil infested with V. dahliae $\left(50 \mathrm{cfu} / \mathrm{g}\right.$ soil) in 1998. $\log _{10}(\mathrm{CFU}+1) \mathrm{V}$. dahliae in $10 \mathrm{mg}$ of dried stem. Mean values for Atlantic and Russet Norkotah were 0.8 and 0.3, respectively.

${ }^{\mathrm{f}}$ Clones inoculated with $10^{7} \mathrm{CFU}$ of $V$. dahliae and 80,000 P. penetrans individuals per plot in $1998 . \log _{10}(\mathrm{CFU}+1) \mathrm{V}$. dahliae in $100 \mu \mathrm{l}$ of stem sap. Mean values for Atlantic and Russet Norkotah were 1.5 and 1.2, respectively.

g Clones inoculated with $10^{7} \mathrm{CFU}$ of $V$. dahliae and 80,000 P. penetrans individuals per plot in $1998 . \log _{10}(\mathrm{CFU}+1)$ V. dahliae in $10 \mathrm{mg}$ of dried stem. Mean values for Atlantic and Russet Norkotah were 0.6 and 0.8 , respectively. 
correlation between sap populations and dry stem populations was not numerically high, but it was highly significant $(r=$ $0.38, P \leq 0.0001)$.

Two clones exhibited consistently high levels of resistance to $V$. dahliae across years, whether $P$. penetrans was present or not (Table 3). Clones C545 and C287 were evaluated in all 3 years and each was superior to the cultivars in all comparisons except one (C545 was not superior to Russet Norkotah and C287 was not superior to Atlantic in 1998).

Resistance to early blight. In 1996 and 1997, early blight ratings were recorded throughout the latter part of the season, but only the maximum score recorded for a clone was used in the data analysis. Year and clone-year effects were highly significant $(P \leq 0.0001$ and $P=0.0417$, respectively) for the maximum early blight rating. Mean ratings were higher in 1997 (2.36) than in 1996 (1.41).

It was possible to calculate days to maturity in 1996 and 1997 because maturity ratings were taken throughout the season.
Year but not clone-year, interactions were significant $(P \leq 0.0001)$ for days to maturity. On average, the cultivars and clones matured later in 1997 (109 days) than in 1996 (97 days). There was a significant negative correlation between maximum early blight rating and days to maturity in the 1996 ( $r=-0.16, P \leq 0.0119)$, but in not the 1997 trial. The correlation between vine health and maturity was also significant in 1998 ( $r=0.45, P<0.0001)$.

Two clones exhibited some early blight resistance that did not appear to be due to late maturity (Table 4). C470 was as early maturing as Russet Norkotah in all years, but was significantly more resistant to early blight in 1996 and 1997. In 1998, C545 was earlier than Atlantic and more resistant to early blight.

\section{DISCUSSION}

The results of a single-year study must be interpreted with caution, but the screening method used for this study has been reported to successfully rate plants for soft rot resistance (21). In addition, Russet
Norkotah is relatively resistant to soft rot caused by E. carotovora subsp. atroseptica (3), so it is a good cultivar to use for comparison. Soft rot resistance has been reported in three of the four exotic species in the backgrounds of the resistant test clones. These include chc, tar, and phu $(3,4,7,38)$.

It was not surprising to find significant environment and genotype-environment effects for the amount of surface area covered with scab lesions because environmental variables such as soil moisture (20) and temperature (1) affect incidence of scab. Haynes et al. (13) have reported similar findings.

All three cultivars are considered to have resistance to scab (28), so they provide a good comparison for the identification of highly resistant clones. In 1996, the test site induced a high enough incidence of scab in the cultivars to detect test clones with significantly higher levels of resistance, but scab incidence was too low in 1998. Although genotypeenvironment effects were detected for tuber surface area covered by scab, similar

Table 4. Comparisons for vine maturity (Mat) and resistance to early blight (EB) between cultivars and clones ${ }^{\mathrm{a}}$

\begin{tabular}{|c|c|c|c|c|c|c|c|c|c|c|c|c|c|c|c|c|c|c|c|c|}
\hline \multirow[b]{4}{*}{ Clone } & \multicolumn{8}{|c|}{1996} & \multicolumn{6}{|c|}{1997} & \multicolumn{6}{|c|}{1998} \\
\hline & & & \multicolumn{6}{|c|}{ Comparison } & \multicolumn{6}{|c|}{ Comparison } & \multicolumn{6}{|c|}{ Comparison } \\
\hline & \multicolumn{2}{|c|}{ Mean } & \multicolumn{2}{|c|}{ Atl } & \multicolumn{2}{|c|}{$\mathbf{R B}$} & \multicolumn{2}{|c|}{$\mathbf{R N}$} & \multicolumn{2}{|c|}{ Mean } & \multicolumn{2}{|c|}{ Atl } & \multicolumn{2}{|c|}{$\mathbf{R N}$} & \multicolumn{2}{|c|}{ Mean } & \multicolumn{2}{|c|}{ Atl } & \multicolumn{2}{|c|}{$\mathbf{R N}$} \\
\hline & Mat & $\overline{E B}$ & Mat & EB & Mat & EB & Mat & EB & Mat & EB & Mat & EB & Mat & EB & Mat & EB & Mat & EB & Mat & EB \\
\hline C118 & 92 & 1.7 & $\mathrm{~S}$ & - & $\mathrm{S}$ & - & $\mathrm{S}$ & - & 102 & 1.5 & $\mathrm{~S}$ & - & $\mathrm{S}$ & - & 1.0 & 0 & $\mathrm{E}$ & - & $\mathrm{S}$ & - \\
\hline C206 & 94 & 2.0 & $S$ & - & $S$ & - & $\mathrm{S}$ & - & $\mathrm{nt}$ & $\mathrm{nt}$ & $\mathrm{nt}$ & $\mathrm{nt}$ & $\mathrm{nt}$ & $\mathrm{nt}$ & 2.0 & 53 & $\mathrm{~L}$ & $* *$ & $\mathrm{~L}$ & $* *$ \\
\hline $\mathrm{C} 251$ & 86 & 2.0 & $\mathrm{~S}$ & - & $S$ & - & $\mathrm{S}$ & - & 106 & 1.5 & $\mathrm{~S}$ & - & $\mathrm{S}$ & - & 1.0 & 0 & $\mathrm{E}$ & - & $\mathrm{S}$ & - \\
\hline C264 & 102 & 2.0 & $\mathrm{~L}$ & - & $\mathrm{S}$ & - & $\mathrm{S}$ & - & 102 & 2.5 & $\mathrm{~S}$ & - & $\mathrm{S}$ & - & 2.8 & 9 & $\mathrm{~L}$ & $* *$ & $\mathrm{~L}$ & $* *$ \\
\hline C287 & 98 & 1.1 & $\mathrm{~S}$ & - & $\mathrm{S}$ & - & $S$ & - & 106 & 1.5 & $\mathrm{~S}$ & - & $\mathrm{S}$ & - & 2.0 & 20 & $S$ & - & $S$ & - \\
\hline C292 & 102 & 0.3 & $\mathrm{~L}$ & $* *$ & $\mathrm{~S}$ & $* *$ & $S$ & $* *$ & 122 & 2.5 & $\mathrm{~S}$ & - & $\mathrm{L}$ & - & 3.0 & 70 & $\mathrm{~L}$ & $* *$ & $\mathrm{~L}$ & $* *$ \\
\hline C41 & 102 & 1.3 & $S$ & - & $\mathrm{S}$ & - & $\mathrm{S}$ & - & 114 & 3.0 & $\mathrm{~S}$ & - & $\mathrm{S}$ & - & 2.3 & 0 & $S$ & - & $\mathrm{L}$ & - \\
\hline C414 & 101 & 0.9 & $\mathrm{~L}$ & $*$ & $\mathrm{~S}$ & $* *$ & $\mathrm{~S}$ & - & 111 & 2.0 & $\mathrm{~S}$ & - & $\mathrm{S}$ & $* *$ & 2.5 & 61 & $\mathrm{~L}$ & $*$ & $\mathrm{~L}$ & $*$ \\
\hline C442 & 98 & 1.0 & $\mathrm{~S}$ & - & $S$ & - & $\mathrm{S}$ & - & 117 & 3.0 & $\mathrm{~S}$ & - & $\mathrm{S}$ & - & 2.3 & 6 & $\mathrm{~L}$ & - & $\mathrm{L}$ & $*$ \\
\hline C447 & 106 & 1.4 & $\mathrm{~L}$ & - & $S$ & - & $\mathrm{L}$ & - & 114 & 1.5 & $\mathrm{~S}$ & - & $\mathrm{S}$ & - & 2.5 & 6 & $\mathrm{~L}$ & $*$ & $\mathrm{~L}$ & $* *$ \\
\hline C470 & 89 & 1.0 & $\mathrm{~S}$ & - & $\mathrm{S}$ & $*$ & $\mathrm{E}$ & - & 114 & 2.0 & $\mathrm{~S}$ & - & $\mathrm{S}$ & $*$ & 2.0 & 0 & $\mathrm{~S}$ & - & $\mathrm{S}$ & - \\
\hline C499 & 108 & 0.7 & $\mathrm{~L}$ & $*$ & $\mathrm{~S}$ & $* *$ & $\mathrm{~L}$ & - & 111 & 2.5 & $S$ & - & $\mathrm{S}$ & - & 1.0 & 1 & $\mathrm{E}$ & - & $\mathrm{S}$ & - \\
\hline C51 & 101 & 1.7 & $\mathrm{~S}$ & - & $S$ & - & $\mathrm{S}$ & - & 97 & 3.5 & $\mathrm{~S}$ & - & $\mathrm{S}$ & - & 1.0 & 0 & $\mathrm{E}$ & - & $\mathrm{S}$ & - \\
\hline C545 & 97 & 2.2 & $S$ & - & $S$ & - & $\mathrm{S}$ & - & 88 & 1.5 & $\mathrm{~S}$ & - & $\mathrm{S}$ & - & 1.0 & 0 & $\mathrm{E}$ & $*$ & $S$ & - \\
\hline C558 & 101 & 1.3 & $\mathrm{~L}$ & - & $\mathrm{S}$ & - & $\mathrm{S}$ & - & 106 & 2.5 & $\mathrm{~S}$ & - & $\mathrm{S}$ & - & 2.0 & 58 & $\mathrm{~S}$ & $* *$ & $\mathrm{~L}$ & - \\
\hline C571 & 96 & 1.0 & $\mathrm{~S}$ & - & $\mathrm{S}$ & $*$ & $S$ & - & 113 & 2.5 & $\mathrm{~S}$ & - & $\mathrm{S}$ & $*$ & 3.0 & 0 & $\mathrm{~L}$ & - & $\mathrm{L}$ & - \\
\hline C589 & 99 & 1.3 & $\mathrm{~S}$ & - & $\mathrm{S}$ & - & $\mathrm{S}$ & - & $\mathrm{nt}$ & $\mathrm{nt}$ & $\mathrm{nt}$ & $\mathrm{nt}$ & nt & nt & 2.8 & 14 & $\mathrm{~L}$ & - & $\mathrm{L}$ & - \\
\hline C590 & 88 & 1.8 & $\mathrm{~S}$ & - & $\mathrm{S}$ & - & $\mathrm{S}$ & - & 102 & 3.0 & $\mathrm{~S}$ & - & $\mathrm{S}$ & - & 1.3 & 1 & $\mathrm{~S}$ & - & $\mathrm{S}$ & - \\
\hline C6 & 94 & 2.2 & $\mathrm{~S}$ & - & $\mathrm{S}$ & - & $S$ & - & 97 & 2.0 & $\mathrm{~S}$ & - & $\mathrm{S}$ & $* *$ & 1.5 & 4 & $\mathrm{~S}$ & - & $\mathrm{L}$ & - \\
\hline C600 & 88 & 1.5 & $\mathrm{~S}$ & - & $\mathrm{S}$ & - & $\mathrm{S}$ & - & 102 & 2.5 & $\mathrm{~S}$ & - & $\mathrm{S}$ & - & 1.0 & 0 & $\mathrm{E}$ & - & $\mathrm{S}$ & - \\
\hline C635 & 94 & 1.3 & $\mathrm{~S}$ & - & $\mathrm{S}$ & - & $\mathrm{S}$ & - & 102 & 3.0 & $\mathrm{~S}$ & - & $\mathrm{S}$ & - & 1.8 & 6 & $\mathrm{~S}$ & - & $\mathrm{L}$ & - \\
\hline I35.05 & 98 & 1.3 & $\mathrm{~L}$ & - & $S$ & - & $\mathrm{S}$ & - & 124 & 3.0 & $\mathrm{~L}$ & - & $\mathrm{L}$ & - & 3.0 & 58 & $\mathrm{~L}$ & $* *$ & $\mathrm{~L}$ & $* *$ \\
\hline Т56.08 & 97 & 1.1 & $\mathrm{~S}$ & - & $\mathrm{S}$ & - & $\mathrm{S}$ & - & 119 & 2.0 & $\mathrm{~S}$ & - & $\mathrm{L}$ & - & 3.0 & 14 & $\mathrm{~L}$ & $*$ & $\mathrm{~L}$ & $* *$ \\
\hline Т56.17 & 92 & 1.2 & $\mathrm{~S}$ & - & $\mathrm{S}$ & - & $\mathrm{S}$ & - & 92 & 2.5 & $\mathrm{~S}$ & - & $\mathrm{E}$ & $*$ & 1.8 & 2 & $\mathrm{~S}$ & - & $\mathrm{L}$ & $*$ \\
\hline V48.03 & 99 & 0.8 & $\mathrm{~S}$ & $* *$ & $\mathrm{~S}$ & $* *$ & $\mathrm{~S}$ & $*$ & 124 & 2.5 & $\mathrm{~L}$ & - & $\mathrm{L}$ & - & $\mathrm{nt}$ & $\mathrm{nt}$ & $\mathrm{nt}$ & $\mathrm{nt}$ & $\mathrm{nt}$ & $\mathrm{nt}$ \\
\hline V50.02 & 94 & 1.0 & $\mathrm{~S}$ & - & $\mathrm{S}$ & - & $\mathrm{S}$ & - & $\mathrm{nt}$ & $\mathrm{nt}$ & $\mathrm{nt}$ & $\mathrm{nt}$ & nt & $\mathrm{nt}$ & $\mathrm{nt}$ & $\mathrm{nt}$ & $\mathrm{nt}$ & $\mathrm{nt}$ & nt & $\mathrm{nt}$ \\
\hline V51.03P & $\mathrm{nt}$ & $\mathrm{nt}$ & $\mathrm{nt}$ & $\mathrm{nt}$ & $\mathrm{nt}$ & $\mathrm{nt}$ & nt & $\mathrm{nt}$ & 124 & 2.5 & $\mathrm{~L}$ & - & $\mathrm{L}$ & - & 4.0 & 81 & $\mathrm{~L}$ & $* *$ & $\mathrm{~L}$ & $* *$ \\
\hline V51.03R & nt & $\mathrm{nt}$ & nt & nt & $\mathrm{nt}$ & nt & nt & nt & $\mathrm{nt}$ & $\mathrm{nt}$ & $\mathrm{nt}$ & $\mathrm{nt}$ & $\mathrm{nt}$ & nt & 1.8 & 1 & $\mathrm{~S}$ & - & $\mathrm{S}$ & - \\
\hline V54.04 & 100 & 0.0 & $\mathrm{~L}$ & $* *$ & $\mathrm{~S}$ & $* *$ & $\mathrm{~S}$ & $* *$ & 113 & 2.0 & $\mathrm{~S}$ & - & $\mathrm{S}$ & $* *$ & nt & nt & nt & $\mathrm{nt}$ & nt & $\mathrm{nt}$ \\
\hline V54.19 & 95 & 2.1 & - & - & - & - & - & - & 108 & 2.5 & - & - & - & - & 1.0 & 0 & $\mathrm{E}$ & - & - & - \\
\hline
\end{tabular}

a Cultivars: Atl = Atlantic, RB = Russet Burbank, and RN = Russet Norkotah. Level of significance between the commercial cultivar and the clone for the disease rating as determined by $t$ test, where $* *=$ clone is more resistant than the cultivar at $P \leq 0.01$, $*=$ clone is more resistant than the cultivar at $P \leq 0.05,-=$ difference not significant or the clone is significantly more susceptible than the cultivar, and nt $=$ not tested. $\mathrm{S}=$ the clone has the same as the cultivar, $\mathrm{E}=$ the clone matures earlier than the cultivar, $\mathrm{L}=$ the clone matures later than the cultivar. Mat = days to maturity in 1996 and 1997 ; in 1998 , vine maturity was based on a rating of 1 (dead) to 5 (early flower). The average value for Atlantic was 94, 106, and 1.8 in 1996, 1997, and 1998, respectively. The average value for Russet Norkotah was 98, 102, and 1.0, in 1996, 1997, and 1998, respectively. The average value for Russet Burbank was 97 in 1996. Early blight ratings were based on a 0-to-4 rating system in 1996 and $1997(0=$ no lesions, $4=80$ to $100 \%$ of the foliage with lesions $)$ and on percentage of healthy foliage in $1998(0=$ no foliage free of lesions, $100 \%=$ no foliar symptoms). The average value for Atlantic was 1.6, 2.5, and 0.5 in 1996, 1997, and 1998, respectively. The average value for Russet Norkotah was 1.8, 3.0, and 0.0 in 1996, 1997, and 1998, respectively. The average value for Russet Burbank was 1.4 in 1996. 
effects were not detected for percentage of tubers with pitted scab. In contrast, Haynes et al. (13) observed significant genotypeenvironment interactions for both surface area covered by scab and severity of scab lesions.

The significant correlation between surface area covered by scab and percentage of tubers with scab lesions corresponds to previous reports (13). The low numerical value of the correlation coefficient indicates that it is better to use both indices in scoring for scab. Haynes et al. (13) found that a combination of the indices effectively identified resistant clones.

Scab resistance in the clones may originate in part from the exotic species in their backgrounds. These clones have genetically diverse backgrounds, containing ber, chc, grl, phu, spl, and tar. Resistance to scab has been reported in chc and phu $(2,26)$.

When the incidence of black scurf was high in $1998,47 \%$ of the test clones outperformed both cultivars. The significant correlation between the incidence of black scurf and pitted scab was not expected. Black scurf is favored by moist soil, whereas scab develops more readily in dry soil (37). In addition, there is no reason to believe that a single genetic system controls resistance to both pathogens. However, the numerical value of the correlation was low, and the correlation between incidence of black scurf and tuber surface area covered by scab was not significant.

The significant environment and genotype-environment interactions detected in this and other studies $(18,46)$ emphasize the need for multiple trials when rating for resistance to Verticillium wilt. Despite environmental effects on disease incidence, the screening field infested with $V$. dahliae consistently provided severe disease pressure, as reflected by the high populations in the sap from stems of the cultivars. Soil populations of $V$. dahliae were lower in the trial with $V$. dahliae $+P$. penetrans than in the trial on the $V$. dahliae in the screening field; therefore, lower levels of stem colonization were expected.

The correlation between stem populations based on sap and those based on dried stems is higher than that reported by Jansky and Rouse (18), but lower than that obtained by Hoyos et al. (15). The correlation is not numerically high; however, the two measures possibly may be detecting different mechanisms of resistance to Verticillium wilt. Stem colonization scores based on sap mainly indicate levels of conidia in living tissues, whereas dried stems probably contain microsclerotia that developed during senescence. Some resistant plants may restrict conidial formation, while others influence the ability of the fungus to generate resting structures.

Clone C287 is highly resistant to $V$. dahliae (18). It was surprising that this clone did not outperform Atlantic in the trial for $V$. dahliae $+P$. penetrans in 1998 when colonization level of dried stems was used as the resistance criterion. In four years of testing this clone (including 1995; data not presented), 108 of 109 stems contained fewer than $40 \mathrm{CFU}$, and V. dahliae was not recovered from 90 of those stems. In 1998, one stem sample contained 500 CFU. It is possible that resistance occasionally breaks down in this clone and, when it does, the fungus reproduces to high levels in the stem. Clone C545 also appears to be very resistant to colonization by $V$. dahliae. It outperformed all cultivars, usually at a high level of significance $(P<$ $0.01)$, in all but one comparison. Like clone C287, most of its stems were free of propagules of $V$. dahliae.

The three clones with consistently high levels of resistance to V. dahliae (C287, C545, and V51.03P) share some parentage in their pedigrees (Table 1). The female parent of C287 is the same as the male parent of C545. The wild species ber and tar are in C287 and C545, while che germ plasm is in both C545 and V51.03P. Resistance to early dying disease also has been reported in ber, chc, grl, spl, and tar $(9,12,22,27)$.

The synergistic interaction between $V$. dahliae and $P$. penetrans in the expression of early dying disease has been well documented $(23,39,48,49)$. In 1998 , five test clones (C118, C206, C264, C414, and C571) had lower levels of stem colonization than the commercial cultivars in the plots with $V$. dahliae $+P$. penetrans, but not on the plot with $V$. dahliae. Although these clones may not be resistant to high populations of $V$. dahliae alone, they seem to minimize the effects of $P$. penetrans on stem colonization by the fungus.

In 1996 and 1997, clones growing in the presence of $V$. dahliae also were rated for maturity and early blight lesions. Therefore, the later average maturity score in 1997 compared with 1996 could have been due in part to the higher incidence of early dying disease in 1996.

In 1998, clones were rated on a field without $V$. dahliae, on a single date using the standard maturity scale. In another plot, estimates of vine health were used to rate for early blight resistance. This approach did not allow the 1998 data to be compared with that from the previous 2 years. The use of a percentage disease rating rather than a five-point scale, however, provided more precision in rating the plants and was probably the reason for better separation of clones in the statistical analysis in 1998. According to Christ (8), estimation of percentage of leaf area covered with early blight lesions, assessed over several dates, provides the most information for early blight scoring. Although the 1998 data are from a single rating date, they are based on an estimation of the leaf area covered with lesions.
In 1996 and 1998, late maturity was associated with early blight resistance, as indicated by significant correlation coefficients. The relationship between late maturity and apparent resistance to early blight is well documented $(5,8,14,19)$. The numerical values of these correlation coefficients were not high in any year; therefore, some clones with true resistance may exist in these populations.

Two clones (C470 and C545) appear to be sources of some early blight resistance. In some comparisons, they were more resistant to early blight and matured as early as the commercial cultivars. These clones contain the species ber, chc, grl, and $\mathrm{spl}$ in their pedigrees. Resistance to early blight has been reported in chc and tar $(4,32)$.

Although there is considerable interest in the use of exotic potato germ plasm in breeding programs, Plaisted and Hoopes (34) indicate that emphasis on transgenic plants is shifting support away from traditional breeding methods. They suggest that the single gene substitutions produced in transgenic plants are useful in prolonging the use of existing cultivars, but sexual hybrids are important for producing broadspectrum changes.

Results of this study underscore the value of interspecific hybridization for the development of disease resistant potato clones. Most of the clones used in this study had not undergone previous selection for disease resistance. All of the 32 clones tested outperformed at least one cultivar for at least one disease resistance trait. In addition, many clones outperformed the cultivars for multiple traits. Clone C545 appears to be especially outstanding, exhibiting resistance to soft rot, scab, pitted scab, early dying disease, and early blight.

Resistance can be transferred from diploids to tetraploid cultivars using the ploidy manipulations outlined by Peloquin and Ortiz (33). Tetraploid $\times$ diploid crosses have successfully transferred to the tetraploid level resistance to common scab (26), early blight (14), and bacterial wilt (47).

Studies are currently underway to determine the feasibility of transferring multiple forms of disease resistance to the tetraploid level via sexual polyploidization and somatic doubling schemes. In addition, tbr haploids are being screened for the expression of disease resistance traits that might result from segregation of tetraploid parental genomes.

\section{ACKNOWLEDGMENTS}

We thank A. MacGuidwin for performing the Pratylenchus penetrans inoculations and assays.

\section{LITERATURE CITED}

1. Agrios, G. N. 1978. Plant Pathology. 2nd ed. Academic Press, Inc., New York.

2. Alam, Z. 1972. Inheritance of scab resistance in 24-chromosome potatoes. Ph.D. thesis, 
University of Wisconsin. Diss. Abstr. Int. 32B (12):6764-6765.

3. Bains, P. S., Bisht, V. S., Lynch, D. R., Kawchuk, L. M., and Helgeson, J. P. 1999. Identification of stem soft rot (Erwinia carotovora subspecies atroseptica) resistance in potato. Am. J. Potato Res. 76:137-141.

4. Bamberg, J. B., Martin, M. W., and Schartner, J. J. 1994. Elite selections of tuber-bearing Solanum species germplasm. Inter-Regional Potato Introduction Station, NRSP-6. Sturgeon Bay, WI.

5. Brandolini, A. 1992. Genetical variation for resistance to Alternaria solani in an advanced population of potatoes. Ann. Appl. Biol. 120:353-360.

6. Butterfield, E. J., and DeVay, J. E. 1977. Reassessment of soil assays for Verticillium dahliae. Phytopathology 67:1073-1078.

7. Carputo, D., Speggiorin, M., Garreffa, P., Raio, A., and Monti, L. M. 1996. Screening for resistance to tuber soft rot and blackleg in diploid Solanum species and $S$. tuberosum hybrids. J. Genet. Breed. 50:221-226.

8. Christ, B. J. 1991. Effect of disease assessment method on ranking potato cultivars for resistance to early blight. Plant Dis. 75:353356.

9. Concibido, V. C., Secor, G. A., and Jansky, S. H. 1994. Evaluation of resistance to Verticillium wilt in diploid, wild potato interspecific hybrids. Euphytica 76:145-152.

10. Dziewonska, M. A., and Was, M. 1994. Diploid genotype DW 84-1457, highly resistant to potato leaf roll virus (PLRV). Potato Res. 37:217-224

11. FAO Production Yearbook. 2002. Volume 54, p. 96. Rome, Italy.

12. Hawkes, J. G. 1990. The Potato: Evolution, Biodiversity, and Genetic Resources. Belhaven Press, London.

13. Haynes, K. G, Goth, R. W., and Young, R. J. 1997. Genotype $\times$ environment interactions for resistance to common scab in tetraploid potato. Crop Sci. 37:1163-1167.

14. Herriott, A. B., Haynes, F. L., Jr., and Shoemaker P. B. 1990. Inheritance of resistance to early blight disease in tetraploid $\mathrm{x}$ diploid crosses of potatoes. HortScience 25:224-226.

15. Hoyos, G. P., Zambino, P. J., and Anderson, N. A. 1991. An assay to quantify vascular colonization of potato by Verticillium dahliae. Am. Potato J. 68:727-742.

16. Iwanaga, M., Jatala, P., Ortiz, R., and Guevara, E. 1989. Use of FDR 2n pollen to transfer resistance to root knot nematode, Meloidogyne incognita, into cultivated 4x potatoes from $2 \mathrm{x}$ wild species. J. Am. Soc. Hortic. Sci. 114:1008-1014.

17. Jansky, S. H. 2000. Breeding for disease resistance in potato. Plant Breed. Rev. 19:69-155.

18. Jansky, S. H., and Rouse, D. I. 2000. Identification of potato interspecific hybrids resistant to Verticillium wilt and determination of criteria for resistance assessment. Potato Res. 43:239-251.
19. Johanson, A., and Thurston, H. D. 1990. The effect of cultivar maturity on the resistance of potatoes to early blight caused by Alternaria solani. Am. Potato J. 67:615-623.

20. Lapwood, D. H. 1973. Irrigation as a practical means to control potato common scab (Streptomyces scabies): Final experiment and conclusions. Plant Pathol. 22:35-41.

21. Lojkowska, E., and Kelman, A. 1994. Comparison of the effectiveness of different methods of screening for bacterial soft rot resistance of potato tubers. Am. Potato J. 71:99113.

22. Lynch, D. R., Kawchuk, L. M., and Hachey, J. 1997. Identification of a gene conferring high levels of resistance to Verticillium wilt in Solanum chacoense. Plant Dis. 81:1011-1014.

23. MacGuidwin, A. E., and Rouse, D. I. 1990. Role of Pratylenchus penetrans in the potato early dying disease of Russet Burbank potato. Phytopathology 80:1077-1082.

24. Mendoza, H. A., and Martin, C. 1989. Breeding for resistance to early blight (Alternaria solani). Pages 119-137 in: Fungal Diseases of the Potato. CIP, Lima, Peru.

25. Mooney, J. J. 1989. Utilization of wild Solanum species for resistance to the Colorado potato beetle and the green peach aphid. M.S. thesis. North Dakota State University, Fargo.

26. Murphy, A. M., De Jong, H., and Tai, G. C. C. 1995. Transmission of resistance to common scab from the diploid to the tetraploid level via $4 \mathrm{x}-2 \mathrm{x}$ crosses in potatoes. Euphytica 82:227-233.

27. Ochoa, C. M. 1990. Pages $78-83$ in: The Potatoes of South America: Bolivia. Cambridge University Press, Cambridge, UK.

28. O'Keefe, R. 1978. North American Potato Variety Handbook. University of Maine, Orono, ME.

29. Ortiz, R. 1998. Potato breeding via ploidy manipulations. Plant Breed. Rev. 16:15-86.

30. Ortiz, R., Iwanaga, M., and Peloquin, S. J. 1994. Breeding potatoes for developing countries using wild tuber bearing Solanum spp. and ploidy manipulations. J. Genet. Breed. 48:89-98.

31. Ortiz, R., Iwanaga, M., Raman, V., and Palacios, M. 1990. Breeding for resistance to potato tuber moth, Phthorimaea opercullela (Zeller), in diploid potatoes. Euphytica 50:119-125.

32. Ortiz, R., Martin, C., Iwanaga, M., and Torres, H. 1993. Inheritance of early blight resistance in diploid potatoes. Euphytica 71:15-19.

33. Peloquin, S. J., and Ortiz, R. 1991. Techniques for introgressing unadapted germplasm to breeding populations. Pages 485-507 in: Plant Breeding in the 1990s. H. T. Stalker and J. P. Murphy, eds. CAB International, Wallingford, UK

34. Plaisted, R. L., and Hoopes, R. W. 1989. The past record and future prospects for the use of exotic potato germplasm. Am. Potato J. 66:603-627.

35. Prasad, B., and Nagaich, B. B. 1983. Screen- ing potato varieties for multiple resistance to Phoma, Alternaria and Phytophthora blights. Indian J. Agric. Sci. 53:1043-1045.

36. Proudfoot, K. G. 1969. The present status of breeding varieties resistant to potato wart and golden nematode in Newfoundland. Pages 139-140 in: Proc. 4th Triennial Conf. Eur. Assoc. Potato Res. Brest, France.

37. Ross, H. 1986. Potato breeding-Problems and Perspectives. Advances in Plant Breeding. Suppl. 13. J. Plant Breed. Verlag. Paul Parey, Berlin.

38. Rousselle-Bourgeois, F., and Priou, S. 1995. Screening tuber-bearing Solanum spp. for resistance to soft rot by Erwinia carotovora ssp. atroseptica (van Hall) Dye. Potato Res. 38:111-118.

39. Rowe, R. C., Riedel, R. M., and Martin, M. J 1985. Synergistic interactions between Verticillium dahliae and Pratylenchus penetrans in potato early dying disease. Phytopathology 75:412-418.

40. Sieczka, M. T. 1989. Progress in the development of potato clones with multiple resistance to pathogens and pests. Page 205 in: Parental Line Breeding and Selection in Potato Breeding. K. M. Louwes, H. A. J. M. Toussaint, and L. M. W. Delleart, compilers. Proc. Joint. Conf. EAPR-EUCARPIA, Pudoc, Wageningen, the Netherlands.

41. Stevenson, W. R. 1994. The potential impact of field resistance to early blight on fungicide inputs. Am. Potato J. 71:317-324

42. Swiezynski, K. M., Dzienwonska, M. A., and Ostrowska, K. 1989. Resistance to the potato leafroll virus (PLRV) in the progeny of a highly resistant potato clone. Genet. Pol. 34:139-146.

43. Swiezynski, K. M., Schiezka, M. T. Sujkowki, L. S., Zarzyka, H., and ZimnochGuzowska, E. 1991. Resistance to Phytophthora infestans in potato genotype derived from wild species. Plant Breed. 107:28-38.

44. Tarn, T. R., Tai, G. C. C., and De Jong, H. 1992. Breeding potatoes for long-day temperate climates. Plant Breed. Rev. 9:217-232.

45. Thill, C. A., and Peloquin, S. J. 1994. Inheritance of potato chip color at the 24 chromosome level. Am. Potato J. 71:629-646.

46. Treadwell, F. J. 1991. Breeding for resistance to Verticillium wilt in potato. Ph.D. thesis University of Minnesota, St. Paul.

47. Watanabe, K. N., El-Nashar, H., and Iwanaga, M. 1992. Transmission of bacterial wilt resistance by FDR $2 n$ pollen via $4 \mathrm{x}-2 \mathrm{x}$ crosses in potatoes. Euphytica 60:21-26.

48. Wheeler, T. A., and Riedel, R. M. 1994. Interactions among Pratylenchus penetrans, $P$ scribneri, and Verticillium dahliae in the potato early dying disease complex. J. Nematol. 26:228-234.

49. Wheeler, T. A., Rowe, R. C., Riedel, R. M., and Madden, L. V. 1994. Influence of cultivar resistance to Verticillium spp. on potato early dying. Am. Potato J. 71:39-57. 